\title{
FINANCIAL PERFORMANCE ANALYSIS USING INVENTORY TURNOVER RATIO, RECEIVABLE TURNOVER RATIO, AND FIXED ASSET TURNOVER RATIO
}

\author{
Desta Riany*1, Nor Norisanti ${ }^{2}$, Kokom Komariah ${ }^{3}$ \\ Universitas Muhammadiyah Sukabumi, Indonesian*123 \\ destarianyy@gmail.com ${ }^{\star 1}$, nornorisanti@ummi.ac.id ${ }^{2}$ \\ ko2mpuspa@ummi.ac.id ${ }^{3}$
}

Abstract: In the cement sub-sector company on the Indonesia Stock Exchange from 2015 to 2018 cement sales increased but the profits that were earned always decreased. Activities in the company have an important role so that the company's financial performance is in good condition. The purpose of this study is to determine the company's financial performance in terms of its activities. The research method used is quantitative. The data analysis technique used is horizontal analysis with inventory turnover ratio, receivable turnover ratio, and fixed asset turnover ratio. The result of this research is that the decline in the company's financial performance is seen from inventory turnover, receivable turnover, and fixed asset turnover.

Keywords: Financial Performance; Fixed Asset Turnover Ratio; Inventory Turnover Ratio; Receivable Turnover Ratio

\section{INTRODUCTION}

Manufacture industry is one industry that is growing rapidly in Indonesia. According to the Investment Coordinating Board, from basic and chemical industries, multifarious industries, and consumer industries, Indonesia has become the largest manufacturing industry base in ASEAN with contributions reaching $20,27 \%$ on a national scale with manufacturing value added which is currently at $4,5 \%$. (BKPM, n.d).

The cement sub-sector is one of the manufacturing sub-sector from the basic industrial sector and chemical. The basic industry sector and chemical gained $6,48 \%$ in 2019 one of the increases came from the cement sub-sector.

The following are companies listed on the Cement Sub Sector on the Indonesian Stock Exchange:

Table 1. Companies Listed on the Cement Sub Sector on the Indonesian Stock Exchange

\begin{tabular}{ccc}
\hline Company Code & Company Name & IPO \\
\hline SMBR & Semen Baturaja (Persero) Tbk & 28 Juni 2013 \\
SMCB & Semen Indonesian (Persero) & 10 Agustus 1977 \\
SMGR & PT Solusi Bangun Indonesian Tbk & 08 Juli 1991 \\
INTP & Tbk Indocement Tunggal Prakarsa Tbk & 05 Desember 1989 \\
WTON & Wijaya Karya Beton Tbk & 08 April 2014 \\
WSBP & PT Waskita Beton Precast Tbk & 20 September 2016 \\
\hline \multicolumn{2}{c}{ Source: Data from IDX that has been processed by the author (2020) }
\end{tabular}

Based on observations of the financial statements of the cement sub-sector listed on the Indonesian Stock Exchange there are problems in the company's activities. The sales and net profit data in the cement sub-sector experienced a decline and experienced fluctuations from 2016 to 2018. 
The following is sales data and earnings in the cement sub-sector:

Table 2. Sales Data in the Cement Sub-Sector for the 2015-2018 Period

\begin{tabular}{crrr}
\hline Company Code & \multicolumn{3}{c}{ Sales } \\
& $\mathbf{2 0 1 6}$ & $\mathbf{2 0 1 7}$ & \multicolumn{1}{c}{$\mathbf{2 0 1 8}$} \\
\hline INTP & 15.361 & 14.431 & 15.190 \\
SMBR & 1.522 & 1.551 & 1.995 \\
SMCB & 9.458 & 9.382 & 10.377 \\
SMGR & 26.134 & 27.813 & 30.687 \\
WTON & 3.481 & 5.362 & 6.930 \\
WSBP & 4.717 & 7.104 & 8.000 \\
\hline Source: Data from IDX that has been processed by the author $(2020)$
\end{tabular}

Figure 1. Sales Data in the cement Sub-Sector for the 2015-2018 Period

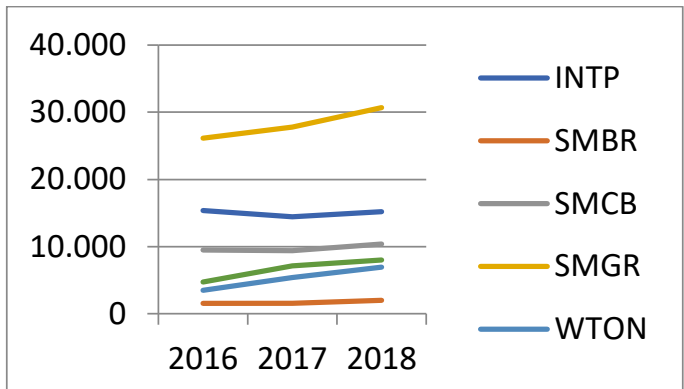

Source: Data from IDX that has been processed by the author (2020)

The following is the earnings data in the cement sub-sector:

Table 3. Earnings Data in the Cement Sub-Sector for the 2015-2018 Period

\begin{tabular}{|c|c|c|c|}
\hline \multirow[t]{2}{*}{ Company Code } & \multicolumn{3}{|c|}{ Earning } \\
\hline & 2016 & 2017 & 2018 \\
\hline INTP & 3.870 & 1.859 & 1.145 \\
\hline SMBR & 274 & 134 & 73 \\
\hline SMCB & (284) & (758) & (827) \\
\hline SMGR & 4.535 & 2.043 & 3.085 \\
\hline WTON & 282 & 340 & 486 \\
\hline WSBP & 634 & 1.000 & 1.103 \\
\hline
\end{tabular}

Source: Data from IDX that has been processed by the author (2020)

Figure 2. Earnings Data in the Cement Sub-Sector for the 2015-2018 Period

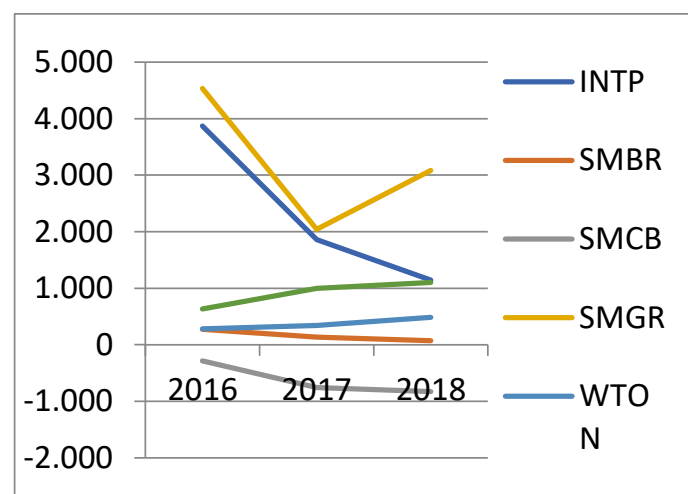

Source: Data from IDX that has been processed by the author (2020) 
From the two tables and two figures above, it can be seen in some companies that sales have increased but net income has decreased. In the case above the volume of cement, sales were not able to encourage profit growth in several companies.

Financial management as an activity of obtaining funds, using funds, and managing assets efficiently requires several goals or objectives. As the normative goal of financial management is related to decisions in the financial sector to maximize the value of the company (Nurhayati, 2017). To realize this the company needs good planning in running its business, so the company can achieve the expected goals. The success of a company's financial performance is in the management's decision to manage the company to generate a lot of profits.

Based on the background of the above problems, the authors wish to research to determine the Company's Financial Performance Using the Inventory Turnover Ratio, Receivable Turnover Ratio, Fixed Asset Turnover Ratio, Total Asset Turnover on Cement Sub Sectors Listed on the Indonesian Stock Exchange.

Financial performance is important in a company. With financial progress, it is known that the company's financial progress has reached its target or not, whether increasing the company's performance increases every period. According to Fahmi (2014), financial performance is an analysis used to see what a company has done by using financial regulations. According to Agus Harjito \& Martono, 2011), all company activities are related to how to raise funds, manage company assets.

The level of effectiveness and efficiency in the use of company assets can be measured by the ratio of activity. The faster the company's resources spin, the more effective and efficient use of these resources, and the greater the profits derived by the company (Anum \& Basri, 2014). Meanwhile, according to Kasmir (2013), the activity ratio is the ratio used to measure the effectiveness of a company in using its assets.

There are several types of activity ratios, there are inventory turnover, receivable turnover, fixed asset turnover. According to Hery (2015), inventory turnover shows the quality of merchandise inventory and management ability in doing sales activity. The higher the inventory turnover, the better the company's performance. Fixed Asset Turnover ratio indicates how well or efficiently a company uses fixed assets to generate sales.

The purpose of this study is to determine the company's financial performance in terms of its activities. From the explanation above, the following framework is obtained:

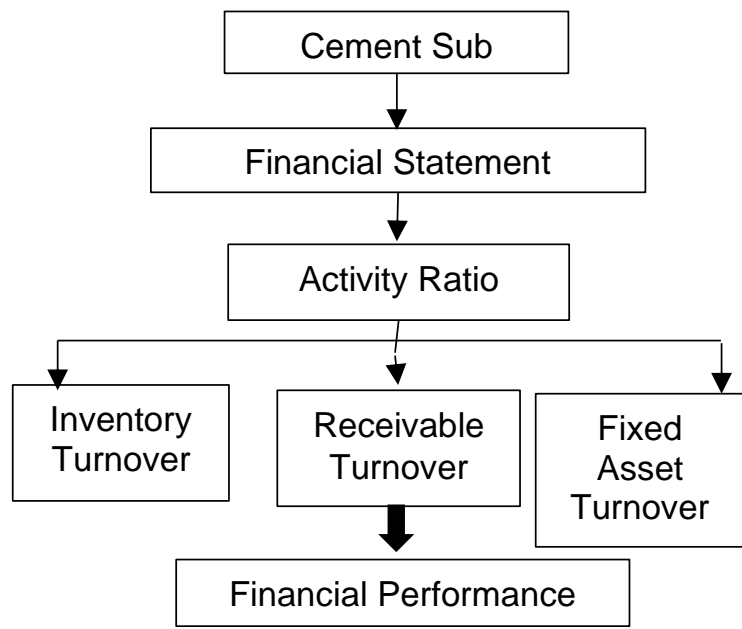

Figure 3. Framework for Thinking

Source: Data has been processed by the author (2020) 


\section{METHODS}

The object of research used is the financial statements in the cement sub-sector registered in the Indonesian Stock Exchange for the period 2016 to 2018. This type of research used in this research is to use a descriptive method with a quantitative approach. The population in this study is the cement sub-sector listed on the Indonesian Stock Exchange. The samples used in this study are Indocement Tunggal Prakarsa Tbk (INTP), Semen Baturaja (Persero) Tbk (SMBR), PT Solusi Bangun Indonesian Tbk (SMCB), Semen Indonesian (Persero) Tbk (SMGR) Wijaya Karya Beton Tbk (WTON) and PT Waskita Beton Precast Tbk (WSBP).

Data collection in this study uses secondary data related to research. In this case, the researchers used a literature study and documentation. Data analysis techniques in this study use horizontal analysis with inventory turnover, receivable turnover, and fixed asset turnover to measure financial performance.

\section{RESULTS AND DISCUSSION}

The results of the calculation of inventory turnover ratio are 2016-2018 of the cement sub-sectors are listed on the Indonesian stock exchange :

Table 4. The Results of the Calculation of Inventory Turnover Ratio

\begin{tabular}{ccccc}
\hline Code & Year & ITO Ratio & $\begin{array}{c}\text { Increased } / \\
\text { Decreased }\end{array}$ & Percent \\
\hline INTP & 2016 & 8,63 times & - & - \\
& 2017 & 8,16 times & $(0,47$ times $)$ & $5,45 \%$ \\
SMBR & 2018 & 8,27 times & 0,11 times & $1,35 \%$ \\
& 2016 & 8,92 times & - & - \\
& 2017 & 7,64 times & $(1,28$ times $)$ & $14,35 \%$ \\
SMCB & 2018 & 6,86 times & $(0,78$ times $)$ & $10,21 \%$ \\
& 2016 & 17,00 times & - & - \\
\multirow{5}{*}{ SMGR } & 2017 & 10,66 times & $(6,34$ times $)$ & $37,29 \%$ \\
& 2018 & 10,79 times & 0,13 times & $1,22 \%$ \\
\multirow{2}{*}{ WTON } & 2016 & 9,78 times & - & - \\
& 2017 & 7,55 times & $(2,23$ times $)$ & $22,80 \%$ \\
& 2018 & 8,66 times & 1,11 times & $14,70 \%$ \\
\multirow{2}{*}{ WSBP } & 2016 & 5,01 times & - & - \\
& 2017 & 5,19 times & 0,18 times & $3,59 \%$ \\
& 2018 & 5,75 times & 0,56 times & $10,79 \%$ \\
& 2016 & 20,42 times & - & - \\
& 2017 & 8,28 times & $(12,14)$ times & $59,45 \%$ \\
& 2018 & 3,60 times & $(4,68$ times $)$ & $56,52 \%$ \\
\hline
\end{tabular}

Source: Data has been processed by the author (2020)

Based on the table above, it can be seen that the financial performance of using the company's inventory turnover ratio is 2016 to 2018 is as follows: in Indocement Tunggal Prakarsa Tbk, PT Solusi Bangun Indonesia Tbk, and Semen Indonesia (Persero) Tbk experienced fluctuations. Indocement Tunggal Prakarsa Tbk in 2016 the inventory turnover was 8,63, then decreased in 2017 to 8,16 and in 2018 it increased to 8,27. PT Solusi Bangun Indonesia Tbk in 2016 the inventory turnover was 17,00 then decreased in 2017 to 10,66 and in 2018 it increased to 10,79. Semen Indonesia (Persero) Tbk in 2016 the inventory turnover was 9,78 then decreased in 2017 to 7,55 and in 2018 it increased to 8,66. Semen Baturaja (Persero) Tbk in 2016 the inventory turnover was 8,92, then decreased in 2017 to 7,64 and in 2018 decreased to 6,86 . PT Waskita Beton Precast Tbk in 2016 the inventory turnover was 20,42 then decreased in 
2017 to 8,28 and in 2018 it decreased to 3,60. The inventory turnover of Wijaya Karya Beton Tbk in 2016 was 5,01, 2017 increased to 5,19, and in 2018 increased to 5,75. The higher the turnover ratio inventory shows inventory merchandise increasingly a little, this means the better for the company, sales increase thus affecting the increase in company capabilities in making a profit.

The results of the calculation of receivable turnover ratio are 2016-2018 of the cement sub-sectors are listed on the Indonesian stock exchange :

Table 5. The Results of the Calculation of the Receivable Turnover Ratio

\begin{tabular}{ccccc}
\hline Code & Year & RTO Ratio & $\begin{array}{c}\text { Increased/ } \\
\text { Decreased }\end{array}$ & Percent \\
\hline INTP & 2016 & 6,06 times & - & - \\
& 2017 & 5,85 times & $(0,21$ times $)$ & $3,47 \%$ \\
SMBR & 2018 & 5,13 times & $(0,72$ times $)$ & $12,31 \%$ \\
& 2016 & 7,35 times & - & - \\
& 2017 & 3,93 times & $(3,42$ times $)$ & $46,53 \%$ \\
SMCB & 2018 & 4,31 times & 0,38 times & $9,67 \%$ \\
& 2016 & 9,24 times & - & - \\
& 2017 & 8,00 times & $(1,24$ times $)$ & $13,42 \%$ \\
SMGR & 2018 & 10,39 times & 2,38 times & $29,88 \%$ \\
& 2016 & 8,17 times & - & - \\
\multirow{3}{*}{ WTON } & 2017 & 6,90 times & $(1,27$ times $)$ & $15,54 \%$ \\
& 2018 & 6,70 times & $(0,20$ times $)$ & $2,90 \%$ \\
& 2016 & 14,69 times & - & - \\
WSBP & 2017 & 14,11 times & $(0,58$ times $)$ & $3,95 \%$ \\
& 2018 & 15,76 times & 1,65 times & $11,70 \%$ \\
& 2016 & 33,22 times & - & - \\
& 2017 & 28,88 times & $(4,34$ times $)$ & $13,06 \%$ \\
& 2018 & 7,87 times & $(21,01$ times $)$ & $72,75 \%$ \\
\hline
\end{tabular}

Based on the table above, it can be seen that the company's financial performance from 2016 to 2018 is as follows: Indocement Tunggal Prakarsa Tbk and Semen Indonesia (Persero) Tbk always decrease every year. In 2016 PT Indocement Tunggal Prakarsa Tbk the receivable turnover was 6,06, decreased in 2017 to 5,85, and in 2018 was 5,13. Receivable turnover in Semen Indonesia (Persero) Tbk 2016 was 8,17, in 2018 decreased to 6,90 and 2018 decreased again to 6,70.

The receivable turnover in Semen Baturaja (Persero) Tbk, PT Solusi Bangun Indonesia Tbk and Wijaya Karya Beton Tbk always fluctuate. In Semen Baturaja (Persero) Tbk 2016 the receivable turnover was 7,35, decreased in 2017 to 3,93, and increased in 2018 to 4,31. The receivable PT Solusi Bangun Indonesia Tbk in 2016 was 9,24, in 2017 decreased to 8,00 and increased in 2018 to 10,39. In Wijaya Karya Beton the receivable turn in 2016 was 14,69, decreased in 2017 to 14,11, and increased in 2018 to 15,76 . The receivable turnover in PT Waskita Beton Precast Tbk always decreased every year, in 2016 was 33,22, 2017 decreased to 28,88, and 2018 decreased again to 7,87 . The higher the accounts receivable turnover rate, the more efficient the receivables are or the faster the receivables are paid by the customer. The more receivables that can be collected by the company, so that it will reduce the existence of uncollectible accounts and facilitate cash flow. 
The results of the calculation of fixed asset turnover ratio are 2016-2018 of the cement sub-sectors are listed on the Indonesian stock exchange:

Table 6. The Results of the Calculation of Fixed Asset Turnover Ratio

\begin{tabular}{ccccc}
\hline Code & Year & $\begin{array}{c}\text { FATO } \\
\text { Ratio }\end{array}$ & $\begin{array}{c}\text { Increased/ } \\
\text { Decreased }\end{array}$ & Percent \\
\hline INTP & 2016 & 1,06 times & - & - \\
& 2017 & 1,12 times & 0,06 times & $5,66 \%$ \\
SMBR & 2018 & 1,23 times & 0,11 times & $9,82 \%$ \\
& 2016 & 1,85 times & - & - \\
& 2017 & 1,38 times & $(0,47$ times $)$ & $25,40 \%$ \\
SMCB & 2018 & 1,47 times & 0,09 times & $6,52 \%$ \\
& 2016 & 3,88 times & - & - \\
& 2017 & 3,21 times & $(0,67$ times $)$ & $17,27 \%$ \\
SMGR & 2018 & 4,00 times & 0,79 times & $24,61 \%$ \\
& 2016 & 2,52 times & - & - \\
WTON & 2017 & 2,02 times & $(0,50$ times $)$ & $19,84 \%$ \\
& 2018 & 1,92 times & $(0,10$ times $)$ & $4,95 \%$ \\
& 2016 & 1,43 times & - & - \\
WSBP & 2017 & 1,23 times & $(0,20$ times $)$ & $13,99 \%$ \\
& 2018 & 1,18 times & $(0,05$ times) & $4,07 \%$ \\
& 2016 & 0,58 times & - & - \\
& 2017 & 0,61 times & 0,03 times & $5,17 \%$ \\
& 2018 & 0,78 times & 0,17 times & $27,87 \%$ \\
\hline \multirow{4}{*}{ Source: Data has been processed by the author $(2020)$}
\end{tabular}

Based on the table above, it can be seen that the financial performance of using the company's fixed asset turnover ratio is 2016 to 2018 is as follows:

In Indocement Tunggal Prakarsa Tbk always increased every year, in 2016 the fixed asset turnover was 1,06, in 2017 increased to 1,12, in 2018 increased to 1,23. In Semen Baturaja (Persero) Tbk fluctuate every year, in 2016 was 1,85, in 2017 decreased to 1,38, and in 2018 increased to $1,47$.

In Solusi Bangun Indonesia Tbk also fluctuate, in 2016 the fixed asset was 3,88, decreased in 2017 to 3,21 , and increased in 2018 to 4,00. The Fixed asset turn of Semen Indonesia (Persero) Tbk always decreased, in 2016 was 2,52 decreased in 2017 to 2,02 and decreased again in 2018 to 1,92. The fixed asset turnover in Wijaya Karya Beton Tbk also decreased every year, in 2016 was 1,43, in 2017 was 1,23, and decreased again in 2018 to $1,18$.

In PT Waskita Beton Precast Tbk the fixed asset turnover in 2016 was 0,58, increased in 2017 to 0,61 , and increased again in 2018 to 0,78 . The higher the turnover of fixed assets means that the greater the fixed assets generate sales for the company, this is very good for the company's survival.

\section{CONCLUSION}

If measured using inventory turnover ratio the best financial performance is at Wijaya Karya Beton Tbk because the inventory turnover always increased. In Semen Baturaja (Persero) Tbk and PT Waskita Beton Precast Tbk, the financial performance is not good because the inventory tun over always decreased. If measured using receivable turnover ratio Indocement Tunggal Prakarsa Tbk, Semen Indonesia (Persero) Tbk and PT Waskita Beton Precast are not in a good condition because the receivable turnover always decreased from 2016 to 2018.

Meanwhile, if measured using fixed asset turnover ratio the best financial performance is at Indocement Tunggal Prakarsa Tbk and PT Waskita Beton Precast 
Tbk because the fixed asset always increased, and the financial performance is not good condition in Semen Indonesia (Persero) Tbk, Wijaya Karya Beton Tbk because the fixed asset turns over always decreased.

\section{REFERENCES}

Agus Harjito dan Martono. (2011). Manajemen Keuangan. Yogyakarta: Ekonisia. Anum, F. dan, \& Basri, M. (2014). Jurnal Riset Akuntansi dan Bisnis, 14(2), 176-187. BKPM. (n.d.). Badan Koordinasi Penanaman Modal (BKPM). Retrieved July 23, 2020, from https://www.bkpm.go.id/

Fahmi, I. (2014). Analisis Kinerja Keuangan. Bandung: Alfabeta.

Hery. (2015). Analisis Laporan Keuangan. Yogyakarta: CAPS (Capital for Academic Publishing Service).

IDX. (n.d.). PT Bursa Efek Indonesia. Retrieved July 23, 2020, from https://www.idx.co.id/perusahaan-tercatat/laporan-keuangan-dan-tahunan/

Kasmir. (2013). Analisis Laporan Keuangan. Jakarta: PT Rajagrafindo Persada.

Nurhayati, S. (2017). Peranan Manajemen Keuangan dalam. IV(1), 85-94. 